\title{
EXPLORING COMMUNICATION STRATEGIES IN SPEAKING PRACTICE AT SECOND GRADE STUDENTS OF STATE SENIOR HIGH SCHOOL
}

\author{
Febriyano Ramadhan \\ IAIN Syekh Nurjati Cirebon \\ ramadhanfebriyano@gmail.com \\ Sumadi \\ IAIN Syekh Nurjati Cirebon \\ sumadi@syekhnurjati.ac.id. \\ Edy Waloyo \\ IAIN Syekh Nurjati Cirebon \\ edywaloyo@syekhnurjati.ac.id.
}

\begin{abstract}
Speaking is complex skill which includes ability to express ideas, intentions, and emotions of the speaker. Mastering speaking skill, students can convey and express their idea and meaning well. Speaking can be mastered by conducting practice in real conversation continuously, and one of the ways is through impromptu conversation designed by teacher. This research aims (1) to investigate communication strategy types employed by second grade students of XI MIPA 2 when performing impromptu conversation with peer in lesson asking and giving opinion with theme go shopping, and (2) to reveal factors that influence the use of particular types of communication strategies. This research applies descriptive qualitative design. Observation, interview, and documentation were carried out to collect the data to answer research questions. The findings show (1) students use five of nine communication strategies in Tarone (1980) taxonomy of communication strategies, namely language switch $(36.93 \%)$, mime $(27.02 \%)$, literal translation $(22.52 \%)$, appeal for assistance $(7.20 \%)$, and approximation $(6.30 \%)$, and (2) the researcher reveals four factors that influence language switch; lack of vocabulary, pronunciation problem, interlocutor, and Indonesian term. Mime is influenced by three factors, such as simple and easy use, vocabulary difficulty, and interlocutor. Literal translation is caused by three factors, namely lack of grammatical knowledge, mother tongue influence, simple and easy use. Likewise, appeal for assistance has three factors; lack of vocabulary, pronunciation problem, and teacher instruction. Last, approximation is caused by two factors, such as conscious and unconscious factor.
\end{abstract}

Keywords: Speaking practice, impromptu conversation, communication problems, communication strategies, second grade students.

\section{BACKGROUND}

In this globalization era, English speaking skills will much help people to communicate with other people from all over the world. Besides, the success of language learning is determined by being able to use that language in real communication (Nunan, 1999).Through speaking; people can convey the idea, message, and purpose to audiences. Speaking is, hence, not just the ability to produce sounds. Moreover, speaking is the 
complex skill which includes the ability to express ideas, intentions, and emotions of the speaker (Huebner, 1960: 4; Stack, 1966: 83; Mackey, 1996: 263; Rivers, 1981: 90). The description above indicates that speaking is one of difficult skill in language learning. It is due to the fact that English is not students' daily language. To master speaking, therefore, is not easy since students do two activities at the same time such thinking of the form and content of utterance they want to deliver.

In this case, English teacher in SMAN 1 Susukan, particularly second grade students of XI MIPA 2 implement impromptu conversation as students' activity in teaching speaking. This is intended to facilitate students to practice speaking skill and habituate them in real life conversation, such as to convey and exchange information or to ask and give opinion in English. The teacher provides several speaking/situation cards which are in relation to topic learnt, namely asking and giving opinion with go shopping as main theme. Students then work in peer group to perform direct or impromptu conversation without looking at text. In other word, students must perform and improvise conversation spontaneously or on the spot with peer based on the card they take randomly.

When performing impromptu conversation, students may face some communication problems that cause them difficult and stuck to convey the intended meaning to peer. The problems may be caused by several factors, such as less vocabulary, lack of grammatical understanding, and poor pronunciation. When it happens, students probably attempt to overcome problems appear during conversation by using alternative way, such as gesture of hand, ask for help, etc. as well as using that strategies to stay conversation continuous. These alternative ways are known as communication strategies (Tarone, 1977; Corder, 1983; Faerch and Kasper, 1983; Bialystok, 1990; Oxford, 1990). Therefore, this research is carried out to figure out how students use communication strategies and its influencing factors in impromptu conversation because theoretically it is helpful to overcome communication difficulty and to maintain conversation flowing as well.

\section{Communication Strategies}

Tarone (1977: 195; 1980: 419) defines communication strategies as strategies used by an individual to handle the problem which happened when language structures are inadequate to convey the ideas (in Oweis, 2013: 246). Meanwhile, according to Corder(1983:16), communication strategies are defined as a systematic technique used by a speaker to express his or her meaning when they faced with some difficulties. The difficulty here means inadequate knowledge of basic grammar and vocabulary in target language. Furthermore, Faerch and Kasper (1983a) define communication strategies as potentially conscious plans for solving what to an individual presents itself as a problem in reaching a particular communicative goal (cited in Dornyei, 1997)

More specifically, Bialystok (1990) points out boarder definition based on three main features:

1. Problematicity: Strategies are adopted when problems in either learning or production are perceived and may interrupt communication. It is not part of the routine operations of language use.

2. Consciousness: This refers either to the learner's awareness that the strategy is being employed for a particular purpose, or the awareness of how that strategy might achieve its intended effect. 
3. Intentionality: This refers to the learner's control over those strategies so that particular ones may be selected from the range of options and deliberately applied to achieve certain effects.

In shorts, from above description, the definitions of communication strategies remain the same; a learners' attempt used by students to cope with communication problem during communicating in English by employing some types of strategies to accomplish successful communication. The strategies carried out by students are generally to seek alternative ways to say the desired word or term when not knowing particular English word. Students can use another way to say the intended meaning by, for instance, using gesture, switching language, describing the object or action, and another alternative way to convey their idea and meaning.

\section{Classification of Communication Strategies}

According to Huang (2010: 89), most communication strategy literature embodies similar and overlapping taxonomies which may be divided into two classifications; avoidance or reduction strategies and achievement or compensatory ones (Tarone, 1980; Faerch \& Kasper,1983; Dornyei \& Scott, 1997). Using the avoidance or reduction strategies (e.g. topic avoidance, message abandonment, meaning replacement), students veer away from unfamiliar topics, avoid solving communication problems, and reduce or abandon the intended point they want to deliver. These behaviors can negatively influence interaction content and are common among low-proficiency learners.

Using the achievement or compensatory strategies, meanwhile, students overcome communication problems by seeking an alternative way or plan for achieving their communication goals. The achievement or compensatory strategies include cooperative strategies (e.g. appeal for assistance) and non-cooperative ones (e.g. L1-based strategies, such as language or code switching, foreignizing, and literal translation; interlanguagebased strategies, such as substitution, generalization, word-coinage, and restructuring; nonverbal strategies, such as mime and imitation). Using these strategies assists students to complete or continue an oral communication and is regarded as good learners' behavior.

\section{Tarone Taxonomy of Communication Strategies.}

Tarone (1980: 429) proposed five categories of communication strategies as follows:

\section{Avoidance}

a. Topic avoidance: to avoid topic due to lack of vocabulary.

b. Message abandonment: leave message unfinished and unclear

\section{Paraphrase}

a. Approximation: seek word which has same or close meaning.

b. Word coinage: create up new or non-existing word.

c. Circumlocution: describe the characteristic of object or action.

\section{Conscious transfer}

a. Literal translation: translate literally word for word from L1 to TL

b. Language switch: switch the word in L1.

4. Appeal for assistance: ask for interlocutor's help to get intended word.

5. Mime: use of non-linguistic strategy, such as gesture, facial expression. 


\section{Speaking}

Johnson and Morrow (1981: 70) stated that speaking, which is generally known with term 'oral communication', is an activity involving two or more people in which listeners and speakers have to react to what they listen and make their contributions at a speed of a high level. Furthermore, Cameron (2001: 40) defined speaking is the use of active language to convey meanings in order to other people can understand it. It is recognized also as an interactive, social and contextualized communicative event. Speaking requires learners to understand how to use language linguistically and pragmatically (Martinez Flor, 2006: 139). Likewise, Finnochiaro and Brumfit (1983: 400) proposed that speaking means giving oral expression to thoughts, opinions and feelings in terms of talk or conversation.

To sum up, speaking is not just the ability to produce sound, but it also requires the comprehensive skill; how people are able to convey thought, feeling, and emotion to other people. Speaking requires two or more people involving in activity in which they have to response each other on what is being talked. When people talk each other, they do not have to understand merely the word linguistically, but also understand the language pragmatically. Those are the key to achieve successful and effective communication

\section{Impromptu Conversation}

According to Cambridge Dictionary, impromptu means something, such as speech, done or composed with little or no preparation. Meanwhile, conversation is kind of spoken language which requires minimally two involved people to exchange opinion, information, feeling, emotion among people as well as to maintain social relationship. In other word, impromptu conversation means conversation performed by two or more people happens spontaneously, unprepared, and on the spot. What is meant by on the spot because students performed conversation with peer based on speaking card provided by teacher with theme go shopping in lesson asking and giving opinion. The students produce utterance on the spot and unplanned because they have to improvise talking about things for shopping. That means they are not required to write or compose dialogue on book beforehand. In that case, students are obligated using some expressions to ask and give opinion as the objective of the lesson and indicators that students should meet.

\section{METHOD}

This research applies qualitative method, particularly descriptive qualitative. Descriptive qualitative is applied because this current research is to describe some phenomena and issues occurred in English classroom. This research primarily is to describe communication strategies used by students of XI MIPA and factors influencing particular choice of communication strategies during impromptu conversation with their peer.

\section{Source and Types of Data}

In this research, the researcher collected the data in the form of primary data and secondary data. Primary data is obtained by observing students' speaking practice in impromptu conversation with peer. The students' speaking is recorded and transcribed to analyze the communication strategies use. Secondary data is obtained from teacher interview and other needed document, such as book, journal, research document and relevant sources. In this research, the researcher took documentation such as photos classroom observation, students' activity, etc. This data is by means to support the primary data to answer the research questions. 


\section{Technique of Data Collection}

\section{a. Observation}

The observation was conducted to students' speaking performance in classroom while they are communicating in English with peer. This observation also is intended to seek communication strategies types applied by students during impromptu conversation. The result of observation on students speaking practice then is transcribed and analyzed to know the use of strategies.

\section{b. Interview}

The researcher selected six students, three males and females, as purposive sampling to be interviewed based on their English score over first semester and one teacher as informant. The researcher interviews the students to obtain deep and more information about communication strategies use based on their experiences and several factors affecting the use of particular communication strategies.

\section{c. Documentation}

In this research, the researcher collects some documents, such as lesson plan, speaking transcripts, and interview transcripts, and other needed documents. These documents are necessary to support the research findings.

\section{Technique of Data Analysis}

\section{a. Data Collection}

The researcher will collect the data from observation, interview, and documentation. Interview will be transcribed in order to acquire the descriptive data clearly, so the findings will be written. Observation is carried out in order to get necessary information about phenomenon being investigated.

\section{b. Data Reduction}

Reducing data refers to the process of selecting, focusing, simplifying, abstracting and transforming the data that appear in written up field notes or transcriptions (Miles and Huberman, 1992: 15 in Sugiyono, 2010).Reducing data is needed to erase unimportant data which may not relevant to research purpose. This step will much help the researcher to merely focus on the data being explored.

\section{c. Data Display}

The data are displayed to classify them based on taxonomy including the types of communication strategies and the affecting factors of communication strategies use. This step includes research finding and discussion to answer research questions.

\section{d. Conclusion and Verification}

After conducting previous steps, the researcher will later conclude the findings of research questions and if it needs some clearance, researcher verifies the data until find the appropriate data to be reported. This step will be conducted in sequence. 


\section{FINDINGS}

\section{Types of Communication Strategies Used by Second Grade Students in Speaking Practice}

Based on the result of classroom observation conducted on March, $1-82018$, the researcher figures out students use five of nine communication strategies in Tarone (1980) taxonomy of communication strategies summarized as in table below:

\begin{tabular}{llcc}
\hline No & Communication Strategies & Frequency & Percentage \\
\hline 1 & Topic Avoidance & - & $0 \%$ \\
\hline 2 & Message Abandonment & - & $0 \%$ \\
\hline 3 & Approximation & 7 & $6.30 \%$ \\
\hline 4 & Word Coinage & - & $0 \%$ \\
\hline 5 & Circumlocution & - & $0 \%$ \\
\hline 6 & Literal Translation & 25 & $22.52 \%$ \\
\hline 7 & Language Switch & 41 & $36.93 \%$ \\
\hline 8 & Appeal for Assistance & 8 & $7.20 \%$ \\
\hline 9 & Mime & 30 & $27.02 \%$ \\
\hline & Total & $\mathbf{1 1 1}$ & $\mathbf{1 0 0 \%}$ \\
\hline
\end{tabular}

Table 1. Students' overall use of communication strategies

Table 1 above illustrates the overall use of communication strategies by students of XI MIPA 2. As can be seen, language switch(36.93\%) is used more often than others which mean it is the most dominant strategy used by students with 41 frequent. From the observation data, the students used this strategy because they are lack of word in English, so to keep the conversation flowing they switch the language to easier them communicate the intended meaning. It is then supported from the interview data with some students stating other reasons of using language switch occurred when the students could not recall a word in English and its pronunciation, so they commonly switch the unknown word in Indonesian by means to overcome the difficulty, and to ensure other students comprehend on what is being conveyed.

Mime (27.02\%) occurred 30 times which is the second strategy frequently used by students. They used this strategy in the form of gesture, such hand movement as to clarify and emphasize what they mean, so there will be miscommunication between students and their speaking partner. Other reasons from interviewing selected students stated that they use mime to assist them to communicate the intended word. This is because what they say is not always understood clearly by the interlocutor. Sometimes they need to play with gesture, such hand movement as to help students convey the intended message to their interlocutor.

Literal translation $(22.52 \%)$ is the third most strategy used by students. Students use this strategy when they transfer directly word for word from their native language into English as target language. Students use this strategy because they probably have insufficient knowledge of English grammar. In this case, there are many utterances that are translated literally from Indonesian to English. As result, the English translation sound weird because they translate the phrase following Indonesian sentence pattern. At the time they are speaking, students often omit the auxiliary tobe in nominal sentence. Moreover, they are omitted the auxiliary do in form of question and tend to use declarative sentence in form of question. 
Appeal for assistance (7.20\%), with 8 times appearance, is less appear strategy comparing to those previous three. The students used this strategy to ask direct help to their interlocutor about the word they do not know in English. This strategy also is proper to ask the correct pronunciation to friend or teacher when they feel unconfident to pronounce the specific word. During observation, students commonly use this strategy to get help from their friend about the English word. Yet, there is student using this strategy to ask for translation, so that he can understand his friend saying and able to reply the conversation properly.

Meanwhile, Approximation (6.30\%), with 7 times appearance, is low rate strategies employed by students. They used this strategy to get the word which shares the semantic feature. In other word, students use the word which is closely as possible in meaning with the intended word, whether or not the word they say is wrong. During observation, a few students get confused with the word many and much which is used ask the price or cost of thing. Both two words have the same meaning, but it has differences in usage. The students use approximation in a low rate as not all students know the word which share the same or close meaning in usage.

On the other hand, there are some reasons why students do not use those strategies. During observation, the researcher does not find the utterance which is classified in topic avoidance. The reason is because teacher has decided the speaking lesson about asking and giving opinion which takes go shopping as main theme. The students do perform based on the card speaking they take with their peer, and teacher does not give the chance to change the topic or theme of speaking freely. Likewise, message abandonment does not use because it is categorized as avoidance strategy as topic avoidance. Students take an effort to continue conversation rather than give up and being silent when they stop in mid utterance. Hence, this strategy is not seen during students perform impromptu conversation. Other reasons why students do not use word coinage strategy because they have never thought to create up new non-existing word since the conversation is talking about the daily life which is familiar to them. Otherwise, circumlocution does not appear during observation because some students are lack of vocabulary mastery, and they could not use the extended word in sentence to explain the action or characteristic of object instead of naming it.

\section{Influencing Factors the Use of Communication Strategies in Speaking Practice.}

The researcher interviewed six students to know their experience on the use of communication strategies during English conversation with peer. Moreover, the students were asked about the factors regarding to particular communication strategies use to know their perception on affecting factors when using certain strategies. The questions consist of nine question concerning types of communication strategies, and single question to reveal the factors causing students use particular strategies.

Based on the interview results, the researcher figures out some factors causing particular communication strategies use during practice English conversation with their peer. The discussion of each strategy and its factors is explained below.

\section{a. Language Switch}

Based on interview with six selected students, their response are various and the researcher implies there are four factors causing the language switch use, as follows.

1) Lack of Vocabulary

During observing students' speaking, the researcher found the phenomena in which students do not speak English fluently. Many students often switch the 
language into Indonesian, even though it is the simple English vocabularies. Some of the words, in fact, had been listed by teacher in white board. It means that when students face communication difficulties, they seek the alternative ways to say the intended message. One of the ways is to switch the language into Indonesian. Students' less vocabulary is one of the factors causing students use this strategy during impromptu conversation with their peer as it is stated by three among six students.

2) Pronunciation Problem

Pronunciation is one of the important aspects in speaking. Some communication problem occurred because of the pronunciation is unclear, so it causes misunderstanding between the one who speak and listen. The pronunciation mistake will cause the different meaning. Therefore, another factors causing students use this strategy because they feel hesitate on their pronunciation. They may know some words in English, but they do not know how to pronounce that word correctly. Two students, from interview data, answered that pronunciation problems causing them use this strategy to avoid misunderstanding on peer.

3) Interlocutor

Another factors causing students use this strategy is because of the interlocutor. Only one student answer their peer could be one factor why they switch language during English conversation. The one who speaks and the one who listens may have the same or different ability in English speaking. When researcher asked the factors influence them using language switch, they state not only having inadequate English words, but it is also to get the meaning across to their speaking partner. Thus, their peer can respond the conversation as long as the speaker clarifies and clearers the point to them. Based on interview data, only one students state the external factors, interlocutor, as the reason to use this strategy.

4) Indonesian Term

Another factors causing students use this strategy is because of Indonesian term. Only one of six students answer this. When students speak English, there must be several words which they cannot find its translation in English. This is actually in accordance to the Indonesian term. If students try translating the term in English, the result of translation sounds strange and weird. Instead of doing so, it is much better to keep saying the term in its original language. The reason is because it is difficult to find the English term which has the close meaning with Indonesian term. For example, the name of Indonesian traditional food, nasi lengko, nasi kuning, or place, village, city, etc. can be spoken in its original name rather than translate it into English.

\section{b. Mime}

Based on interview with six selected students, their responses are various and the researcher implies there are three factors causing mime use, as follows.

1) Simple and Easy Use

The first factor causing the use of mime strategy is simple and easy use as stated by two students. Students probably use non-linguistic strategy consciously or unconsciously. As known, the use of gesture during communicating implicitly carries the meaning. People will get mutual understanding, for instance, when the one who speak touch his stomach and showing facial expression like getting pain. 
They may assume that she or he got stomachache even though no said word at all. In other word, people can guess the meaning behind gesture since it is basically contained meaning.

2) Lack of Vocabulary

As noticed in previous discussion, vocabulary limitation during English speaking became the most constraint confronted by students. Above all, the student practice conversation in English in spontaneous way in which they must speak based on the situation card provided by teacher. As known, vocabulary is essential in language which used to compose the sentence and carrying meaning. The way students overcome the vocabulary difficulties are not same. Based on the interview result, two students state the vocabulary limitation caused them using mime to help them explaining the meaning to peer when the vocabulary is unknown to them.

3) Interlocutor

Two students of six stated that interlocutor could be the factors causing use of this strategy. When students talk in English, they may encounter some difficulty, both own and other difficulties. The own problem came when the conversation stop in middle utterance due to students' less vocabulary so they confused what to say next. Other problem is often happened when the peer could not easily catch the point due to inability to understand word meaning. Probably, the peer did not catch the point because the speaker speaks unclear, incorrect pronunciation, or speak so fast, so the use of mime, such gesture is helpful to clarify and emphasize meaning to peer.

\section{c. Literal Translation}

Based on interview with six selected students, their responses are various and the researcher implies there are three factors causing literal translation use, as follows.

\section{1) Grammatical Difficulty}

Two students give response that grammatical difficulty affects the use of this strategy. The researcher implies that the limited knowledge of grammar influence students to use word for word translation intentionally or not. It can be seen when observing their speaking in classroom, student use this strategy with purpose to overcome their own problem due to grammatical difficulty in composing correct English sentence or phrase. In fact, they speak spontaneously on specific theme, so it is difficult for them to speak grammatically correct. Therefore, when using literal translation strategy, the consequence is that students will not focus with the accuracy of speaking.

2) Mother Tongue Influence

Another factor, in students' perspective, causing literal translation use is mother tongue influence as responded by two of six interviewed students. As known generally, English is foreign language. The students learn their mother tongue earlier, Javanese and Indonesian, before learning additional language. When they learn new language, mainly English, their mother tongue, both Javanese and Indonesian, influence the way they learn. This can clearly be seen when they pronounce some English words, the mother tongue effect effects on their accent of English. Another example is, in addition, occurred when they speak English, but it sounds like Indonesian because their English is translated freely from Indonesian phrase or sentence. 
3) Simple and Easy Use

Five of six students, almost all, stated that simple and easy use as the most factors caused them using this strategy. When the researcher conducted interview, almost all students answered they used word for word translation to communicate their message in English. Besides two previous factors, they use literal translation as an alternative way to cope with grammatical difficulty with reason that it is simpler and easier to speak English when translating firstly from Indonesian to English.

\section{d. Appeal for Assistance}

There are three factors that influence the use of this strategy, as follows:

1) Lack of vocabulary

Three students responded that less vocabulary causing them use this strategy to ask for help. Using this strategy is somewhat helpful for them because they keep communicating in English by using the phrase what to say, how to say, what is in English, to convey their meaning when the intended vocabularies are not known to them. Although they did not know some English words, they keep speaking English by asking for help to their peer or teacher to get the intended word, and to stay conversation continuous.

2) Pronunciation Problem

Two students responded that pronunciation problem causing them use this strategy to ask for help. As language learner, students may fell confused about the several words in English which have similar sounds, but different spelling, vice versa. This may be the cause students feel overwhelm when speaking English. To overcome their own difficulty, student asked for help to peer by means his or her peer can help him to fix the difficulty regarding to the correct word or term in English.

3) Teacher Instruction

Three students responded that teacher instruction causing them use this strategy to ask for help. This data is supported from the observation and interview result. The researcher observed teaching-learning process including teacher instruction before students practice conversation with peer. During teaching process, the teacher gave instruction when students did not know or remember some English word, they can ask question to peer and teacher by using English, such as how to pronounce the word "affordable", what is in English "mahal", etc.

\section{e. Approximation}

There are two factors that influence the use of this strategy, as follows:

1) Conscious

Conscious is one of causing factors the use of approximation strategies within students' conversation. It means students are aware using another term or word to express their meaning as close as possible with desired target word. As interview results, there are two students which implicitly stated that they use this strategy consciously when not knowing the word to speak, they find some words which has the close or same meaning 
2) Unconscious

Unconscious is one of causing factors the use of approximation strategies within students' conversation. It means students are not aware using another term or word to express their meaning as close as possible with desired target word. There were two students, from interview data, which explicitly replied that they used this strategy unconsciously

\section{DISCUSSION}

This section discusses the interpretation of research finding on types of communication strategies used by students of XI MIPA 2. Based on the data gathered from observation and interview with six selected students based on their English score, there are three important point to be discussed. First, the findings show that students use five of nine communication strategies in Tarone (1980) taxonomy of communication strategies. Among five used strategies, the researcher is divided into two explanations; the most highly used strategies and less used strategies. The most highly used strategies are language switch, mime, and literal translation. On the other hand, appeal for assistance and approximation is less strategies used by students. The less frequent use of these strategies due to students may face different communication difficulties and causing them use other strategies which they think it is easier to do. Those five strategies employed by students during impromptu conversation are included in compensatory or achievement strategy (Faerch \& Kasper,1983; Dornyei \& Scott, 1997). Using the achievement or compensatory strategies, students handle communication problems by an alternative plan for achieving their original goals (Huang, 2010: 89). Achievement or compensatory strategy includes appeal for assistance as cooperative strategy and non-cooperative ones; L1 based-strategies, such language switch and literal translation as, and mime or non-linguistic strategy. In Huang's word, using those strategies assist students complete or continue an oral communication and is considered as good learner behavior (2010: 89).

Second, the fact appears during observing speaking performance of students. In that case, students with different English score fundamentally use more than one communication strategies in one conversation or utterance. For instance, in producing utterance, students use language switch in one side followed by other strategies based on the encountered problems during spontaneous conversation. In relation to the types of communication strategies, Karimnia \& Zade (2007) state that it is possible that a single utterance is labeled under two different categories. The results found there are some conversations using more than one strategy. This is occurred because the speaking task designed by teacher is to give all students opportunity to practice unplanned conversation based on speaking card as guidelines. Further, students are faced with the situation which they have to speak English on the spot without looking at text. For this reason, students may think hard to express meaning in English, and consequently they may face some problems and use various strategies to overcome problems whether or not it is done intentionally.

Third, each strategy is caused by various factors. Based on the interview result with students, the researcher reports there are four factors causing students use language switch, namely lack of vocabulary mastery, pronunciation difficulty, interlocutor, and Indonesian term. Likewise, the use of mime, called also non-linguistic strategy, such as body and hand movement, facial expression, etc. was caused by three factors, namely simple and easy use, vocabulary difficulty, and interlocutor. The use of literal translation is caused by three 
factors, such as grammatical difficulty, mother tongue influence, and simple and easy use. Besides, the use of appeal for assistance strategy is influenced by three factors, namely lack of vocabulary, pronunciation problem, and teacher instruction. The last factor of this strategy means the teacher has given direct instruction to students to ask in English when facing vocabulary difficulty during practice speaking. Approximation strategy use is influenced by two factors, such as conscious and unconscious factor. Since the conversation is designed immediately in which students have to improvise the conversation based on speaking card, the use of similar word could be occurred either conscious or unconscious.

\section{CONCLUSION}

Based on the findings, discussion, and interpretation of the data, the researcher reports that students use five communication strategies, namely language switch, mime, literal translation, appeal for assistance and approximation in impromptu conversation. Those five used strategies are classified in compensatory or achievement strategy. In other word, when students engage in spontaneous conversation, they are aware to keep the conversation flowing by employing some strategies which is helpful to overcome communication problems due to linguistic elements, such as vocabulary insufficiency, lack of grammar knowledge, and poor pronunciation. Using achievement or compensatory strategies means students take serious effort to cope with communication problems by seeking an alternative way or plan for achieving their communication goals. On the other side, the employment of particular strategies is greatly influenced by various factors as stated by students during interview. These factors make students aware and use some strategies to which handle communication problems as well as to hold conversation continuous during performing impromptu conversation with their peers. Such factors drive students to overcome problems that potentially appear during conveying opinion and information in English to others.

\section{REFERENCES}

Bialystok, E. (1990). Communication Strategies: A Psychological Analysis of Second Language Use. Oxford: Basil Blackwell.

Cameron, L. (2001). Teaching Languages to Young Learner. Cambridge: Cambridge University Press.

Corder, S. (1983). Strategies of Communication. In C. Faerch, \& G. Kasper (Eds.), Strategies in Interlanguage Communication. London: Longman.

Dornyei, Z., \& Scott, M. L. (1997). Communication strategies in a second language: Definitions and taxonomies. Language Learning, 47(1), 173210.http://researchgate.net/

Faerch, C., \& Kasper, G. (1983). Strategies in Inter Language Communication. London: Longman.

Faerch, C \& Kasper, G. (1983a). Plans and Strategies in Foreign Language Communication. In Dornyei, Z., \& Scott, M. L. (1997). Communication Strategies in a Second Language: Definitions and Taxonomies. Language Learning, 47(1), 173210. 
ISSN: 2579-8170 e-ISSN: 2549-5089

Huang, C.P. (2010). Exploring Factors Affecting the Use of Communication Oral Strategies. ELTJournal, 85-103.http://eltjournal.org/

Huebner, T. (1960). Audio Visual Technique in Teaching Foreign Language. New York: New York University Press.

Karimnia, A. and Zade, S.S. (2007). Communication Strategies: English Language Departments in Iran. Iranian Journal of Language Studies (IJLS). (1), 287300.http://eric.ed.gov/

Mackey, F. William. (1996). Language Teaching Analysis. London: Longman and Co. Ltd.

Miles, Mattew B. dan A. M Huberman. (1992). Analisis Data Kualitatif. In Sugiyono. (2010). Penelitian Pendidikan (Pendekatan Kuantitatif, Kualitatif, dan $R \& D$ ). Bandung: Alfabeta.

Nunan, D. (1999). Second Language Teaching and Learning. Boston: Heinle \& Heinle Publishers.

Oweis, T. (2013). A literature review on communication strategies in language learning. European Scientific Journal, edition vol.9, No.26, ISSN: 1857 - 7881. doi: http://eujournal.org/River, Wilga M. (1981). $2^{\text {nd }}$ edition: Teaching Foreign Languange Skill. Chicago: The University of Chicago Press.

Oxford, R. (1990). Language Learning Strategies: What Every Teacher Should Know. New York: Newbury House. In Oweis, T. (2013). A Literature Review on Communication Strategies in Language Learning. European Scientific Journal, edition vol.9, No.26, ISSN: $1857-7881$.

Stack, Edward M. (1966). The Language Laboratory and Modern Language Teaching. New York: Oxford University Press.

Tarone, E. (1977). Conscious communication strategies in inter language: A progress report. In Oweis, T. (2013). A Literature Review on Communication Strategies in Language Learning. European Scientific Journal, edition vol.9, No.26, ISSN: 1857 7881 .

Tarone, E. (1980). Communication Strategies, Foreigner Talk, and Repair in Interlanguage. Language Learning, 30, 417-431.http://researchgate.net/ 